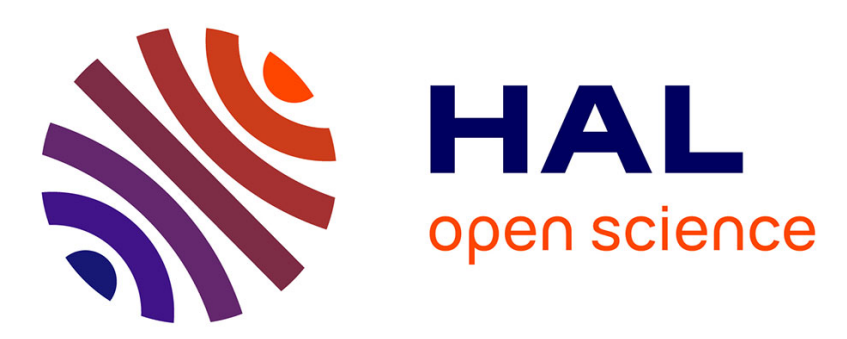

\title{
Performance of U.S. hybrid distributed energy systems: Solar photovoltaic, battery and combined heat and power
}

\author{
Kunal K Shah, Aishwarya S Mundada, J.M. Pearce
}

\section{To cite this version:}

Kunal K Shah, Aishwarya S Mundada, J.M. Pearce. Performance of U.S. hybrid distributed energy systems: Solar photovoltaic, battery and combined heat and power. Energy Conversion and Management, 2015, 105, pp.71-80. 10.1016/j.enconman.2015.07.048 . hal-02119533

\section{HAL Id: hal-02119533 \\ https://hal.science/hal-02119533}

Submitted on 3 May 2019

HAL is a multi-disciplinary open access archive for the deposit and dissemination of scientific research documents, whether they are published or not. The documents may come from teaching and research institutions in France or abroad, or from public or private research centers.
L'archive ouverte pluridisciplinaire HAL, est destinée au dépôt et à la diffusion de documents scientifiques de niveau recherche, publiés ou non, émanant des établissements d'enseignement et de recherche français ou étrangers, des laboratoires publics ou privés. 
Preprint: K.K. Shah, A. S. Mundada, J. M. Pearce. Performance of U.S. Hybrid Distributed Energy Systems: Solar Photovoltaic, Battery and Combined Heat and

Power. Energy Conversion and Management 105, pp. 71-80 (2015). DOI: http://dx.doi.org/10.1016/i.enconman.2015.07.048

\title{
Performance of U.S. Hybrid Distributed Energy Systems: Solar Photovoltaic, Battery and Combined Heat and Power
}

\author{
Kunal K. Shah ${ }^{1}$, Aishwarya S. Mundada ${ }^{1}$, J.M. Pearce ${ }^{1,2, *}$ \\ 1. Department of Electrical \& Computer Engineering, Michigan Technological University \\ 2. Department of Materials Science \& Engineering, Michigan Technological University
}

* Contact author:

601 M\&M Building

1400 Townsend Drive

Houghton, MI 49931-1295

906-487-1466

pearce@mtu.edu

\begin{abstract}
Until recently, the relatively high levelized cost of electricity from solar photovoltaic (PV) technology limited deployment; however, recent cost reductions, combined with various financial incentives and innovative financing techniques, have made PV fully competitive with conventional sources in many American regions. In addition, the costs of electrical storage have also declined enough to make PV+battery systems potentially economically viable for a mass-scale off-grid lowemission transition. However, many regions in the U.S. (e.g. Northern areas) cannot have off-grid PV systems without prohibitively large battery systems. Small-scale combined heat and power (CHP) systems provide a potential solution for off-grid power backup of residential-scale PV+battery arrays, while also minimizing emissions from conventional sources. Thus, an opportunity is now available to maximize the use of solar energy and gain the improved efficiencies possible with CHPs to deploy PV+battery+CHP systems throughout the U.S. The aim of this study is to determine the technical viability of such systems by simulating PV+battery+CHP hybrid systems deployed in three representative regions in the U.S., using the Hybrid Optimization Model for Electric Renewable (HOMER) Pro Microgrid Analysis tool. The results show that the electricity generated by each component of the hybrid system can be coupled to fulfill the residential load demand. A sensitivity analysis of these hybrid off grid systems is carried out as a function capacity factor of both the PV and CHP units. The results show that conservatively sized systems are technically viable in any continental American climate and the details are discussed to provide guidance for both design and deployment of PV+battery+CHP hybrid systems to reduce consumer costs, while reducing energy-and electricity-related emissions.
\end{abstract}

Keywords: photovoltaic; cogeneration; combined heat and power; sizing; HOMER; hybrid system 1. Introduction

Anthropogenic climate destabilization caused by greenhouse gas (GHG) emissions has the potential to upset human welfare, global ecosystems, and the temperate climate in which most people live [1-4]. Both global GHG emissions and global atmospheric carbon dioxide $\left(\mathrm{CO}_{2}\right)$ concentrations are increasing rapidly [1-4]. However, much of the primary energy in fossil fuels is still wasted during conversion to electricity in power plants $[5,6]$. Combined heat and power (CHP) systems can use fossil fuel energy more efficiently, delivering two or more times the useful energy from the same 
Preprint: K.K. Shah, A. S. Mundada, J. M. Pearce. Performance of U.S. Hybrid Distributed Energy Systems: Solar Photovoltaic, Battery and Combined Heat and Power. Energy Conversion and Management 105, pp. 71-80 (2015). DOI: http://dx.doi.org/10.1016/i.enconman.2015.07.048

quantity of fuel, thereby reducing GHG emissions [7-17]. Small-scale CHP systems can also be integrated with solar photovoltaic (PV) arrays, further reducing emissions [18-26]. In residential settings, the waste heat from co-generation units can be used primarily for space heating and cooling and domestic water heating. The use of co-generation units in this way is optimal for energy management [27-29]. First generation PV+CHP hybrids, where the combined PV+battery systems decrease the run time of the co-generation unit, have been investigated extensively for residential applications [18, 20,23,25,26, 30]. Although PV-CHP systems effectively counter the inherent intermittency of solar energy, when designed in this way the thermal energy from the CHP unit is far from fully utilized; that means important quantities of thermal energy will end up being wasted, thus lowering the efficiency of the system in a range of geographic locations [20, 29,31]. Total system efficiency can be increased by utilizing the battery and PV output to reduce CHP runtime.

Such highly-efficient, low-emissions systems have historically been uncommon in the U.S., due primarily to the relatively high levelized cost of electricity (LCOE) available from PV, and off-grid PV systems were not viable in many regions in the U.S. Recent reductions in PV costs have made the LCOE of PV competitive with conventional sources in many American regions [32]. In addition, the costs of batteries have also declined enough [33] to make PV+battery systems potentially economically viable for grid defection [34]. However, many regions in the U.S. (e.g. Northern areas) cannot have off-grid PV systems without prohibitively large battery backups. Thus, an opportunity is now available to maximize the use of solar energy and gain the improved efficiencies possible with CHPs to deploy PV+battery+CHP systems throughout the U.S. The size and operation of such hybrid systems must be designed to match the load and the availability of solar flux, which varies regionally. Computer models are needed to size each component [32]. By doing this the hybrid system overcomes the limitations of i) conventional generation by reducing externalities, ii) radically reduces the size and thus cost of the battery system in a conventional PV+battery off grid system and iii) radically reduces the emissions and concomitant externalities of a micro CHP+battery system.

To meet this objective, this paper uses the Hybrid Optimization Model for Electric Renewable (HOMER) Pro Microgrid Analysis tool to simulate PV+battery+CHP hybrid systems deployed in three representative regions in the U.S. The electricity generated by each component of the hybrid system is coupled to fulfill the residential load demand. Then a sensitivity analysis of these hybrid off grid systems is carried out as a function of the capacity factor of both the PV and CHP units. The modeling results are discussed in detail to provide guidance for both the design and deployment of PV+battery+CHP hybrid systems, to reduce consumer costs and energy-related GHG emissions.

\section{Methodology}

\subsection{System Overview}

The modeled PV+CHP+battery system is depicted in Figure 1 . In this system, only AC loads are considered. In addition, there is a thermal load for heating. Both the PV array and the CHP unit are used to generate electricity. In order to fulfill the electric load, demand conversion and storage equipment for electric loads is also incorporated. For the electric load, an inverter is installed to convert DC output from the battery bank and the PV array, into an AC output compatible with the user load. It should be noted here that this is a conservative and limiting assumption as it would involve the least changes by the users (e.g. it allows consumers to use all of their current appliances rather than switch to DC). Similarly, a rectifier is included to store excess AC output from the CHP 
Preprint: K.K. Shah, A. S. Mundada, J. M. Pearce. Performance of U.S. Hybrid Distributed Energy Systems: Solar Photovoltaic, Battery and Combined Heat and

Power. Energy Conversion and Management 105, pp. 71-80 (2015). DOI: http://dx.doi.org/10.1016/i.enconman.2015.07.048

unit in the battery bank. Parallel topology is employed for the electrical component of the system [36]. The PV and the battery unit will fulfill the load demand, which will help to increase system efficiency. The remaining load demand will be served by the CHP unit. The output of the PV array is filtered using an LC filter in order to reduce the ripple [37]. The DC output from the filter is boosted using a DC-DC boost converter. The boosted DC output is converted into AC using an inverter, which is provided to the load. The CHP unit consists of an internal combustion engine (ICE) and induction motor, which converts natural gas into both electricity and heat. Any excess energy generated by PV and CHP is stored in the battery. The input required by the battery is DC, so a rectifier converts the $\mathrm{AC}$ to $\mathrm{DC}$, which is then fed into the battery.

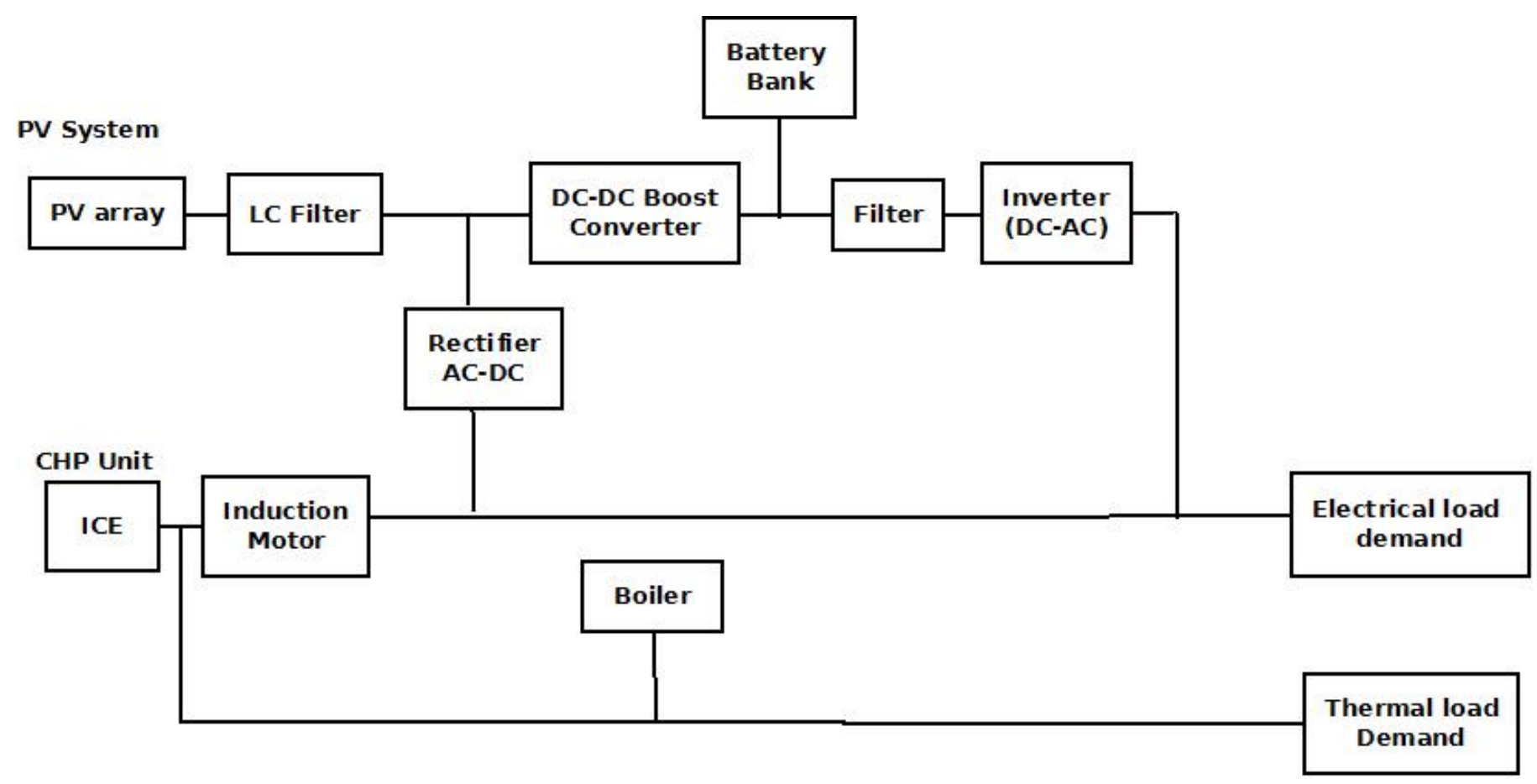

Figure 1. Block diagram of PV+CHP+battery system.

\subsection{Dispatch Strategy}

The control dispatch strategy for the hybrid system, shown in Figure 2, first prioritizes the PV, then battery and then the CHP unit in order to meet the load demand and to increase the efficiency of the system. When output generated by the PV is equal to the AC load then it will try to fulfill the electrical load demand. When the energy generated by the PV unit is greater than the energy required by the load, it will match the electrical demand and the remaining energy is stored in the battery. The energy stored in the battery will be used during times when there is insufficient direct solar energy to match demands. When power generated by the PV unit is less than the load requirement, the energy will be supplied by the both PV unit and the battery to fulfill the load demand. If battery+PV is not able to meet the demand then the battery will be deactivated and the CHP unit is activated. If PV+CHP unit is equal to the load then it will fulfill the electrical demand and control is now provided to fulfill the thermal demand. If the energy generated by the PV+CHP unit is greater than the electrical load, then it will fulfill electrical demand and excess energy will be used to charge the battery. Once the battery is charged and the thermal demand is fulfilled the CHP unit is deactivated for a time. If PV+CHP does not fulfill the electrical demand, then all the three 
Preprint: K.K. Shah, A. S. Mundada, J. M. Pearce. Performance of U.S. Hybrid Distributed Energy Systems: Solar Photovoltaic, Battery and Combined Heat and

Power. Energy Conversion and Management 105, pp. 71-80 (2015). DOI: http://dx.doi.org/10.1016/i.enconman.2015.07.048

units PV+battery+CHP will be activated. When PV+battery+CHP is equal to the AC load, then it will fulfill the electrical demand and control is now provided to fulfill the thermal demand. Once the electrical demand is fulfilled, the CHP unit is deactivated. During the complete process whenever the thermal demand is not fulfilled by CHP it is fulfilled by the boiler (furnace) $[20,21]$.

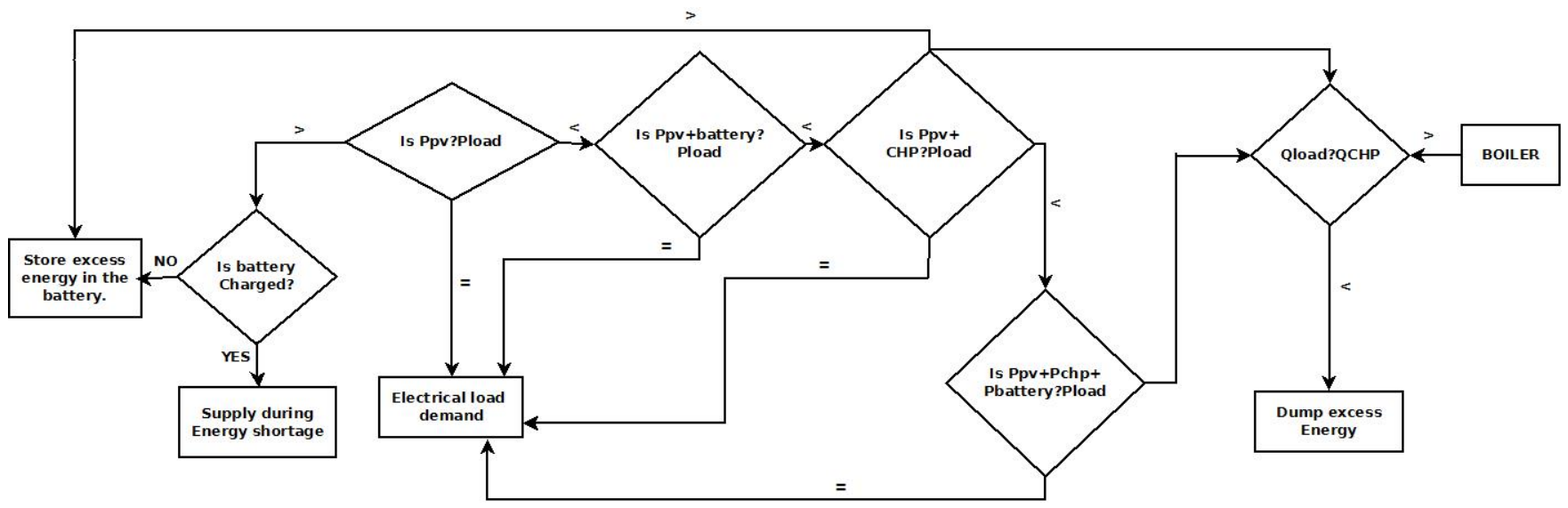

Figure 2. Dispatch strategy for hybrid system.

\subsection{Simulation}

HOMER Pro Microgrid Analysis Tool (3.1.3) was used here and has previously been validated. Figures 1-2 were simulated for three different locations: Prescott, Arizona (representing a hot climate), Sacramento, California (moderate climate) and Houghton, Michigan (cold climate). The hourly residential load requirements for all three regions were obtained from the National Renewable Energy Laboratory database [38]. The hourly solar irradiation data required for the simulation for all the three regions was obtained from the System Advisor Model (SAM-2015 1.30) [39]. As each location has a different load demand and solar flux input, the energy generated by the PV unit, battery and CHP unit will be different and these three systems were sized to meet the demand.

\subsubsection{PV sizing}

In order to determine PV size [40,41] the annual AC load demand [38], average solar hours [42] and derate factor was determined. The derate factor is the percentage of available AC energy compared to the DC rating of the array. The factors use to calculate the DC-AC derate factors are PV module nameplate DC rating, inverter and transformer, mismatch, DC wiring, diodes and connections, soiling, AC wiring, system availability, and shading. The derate factor considered for this paper is 0.75 for all the three regions [43]. The power of the PV system $\left(\mathrm{P}_{\mathrm{s}}\right)$ in $\mathrm{kW}$ is calculated by [40]:

$$
\mathrm{P}_{\mathrm{s}}=\frac{E_{L}}{365 \times S_{H} \times D_{F}}
$$

Where, $E_{L}$ is the annual load demand $[\mathrm{kWh}], \mathrm{S}_{\mathrm{H}}$ is the peak average solar hours per day, and $\mathrm{D}_{\mathrm{F}}$ is the derate factor. Thus equation 1 is simply used to obtain a reasonable approximation of the PV sizing. The actual PV output is calculated by the simulation as discussed below.

Table 1. End-use energy requirements [38] and average solar hours [42]. 
Preprint: K.K. Shah, A. S. Mundada, J. M. Pearce. Performance of U.S. Hybrid Distributed Energy Systems: Solar Photovoltaic, Battery and Combined Heat and

Power. Energy Conversion and Management 105, pp. 71-80 (2015). DOI: http://dx.doi.org/10.1016/i.enconman.2015.07.048

\begin{tabular}{|c|c|c|}
\hline Region & $\begin{array}{c}\text { Average } \\
\text { Solar Hours } \\
\text { per Day }\end{array}$ & $\begin{array}{c}\text { Annual Load } \\
\text { Demand (kWh) }\end{array}$ \\
\hline Prescott & 6 & 8840 \\
\hline Sacramento & 5.5 & 8739 \\
\hline Houghton & 4.1 & 9128 \\
\hline
\end{tabular}

\subsubsection{Battery sizing}

The size of the battery is dependent on the excess energy generated by the PV in a way such that the battery can store the excess energy and utilize it when solar is not available. The hourly electric load demand and the hourly energy generated by the PV module during the peak summer day for all the three regions is shown in Figures 3-5. It should be noted, that for Figures 3-5, the input efficiency is $17.3 \%$ is the STC efficiency. Thus, the electrical energy conversion will vary with each hour because of temperature and solar flux and this is taken into account in the simulation. The energy generated by the PV ( $\left.\mathrm{E}_{\mathrm{pv}}\right)$ module in $\mathrm{kWh}$ is given by [45]: $E_{p v}=S_{F} \times \eta \times A$

Where $S_{F}$ is the solar flux $\left[\mathrm{W} / \mathrm{m}^{2}\right], \eta$ is the efficiency of solar module [\%], and A is the area of PV module $\left[\mathrm{m}^{2}\right]$.

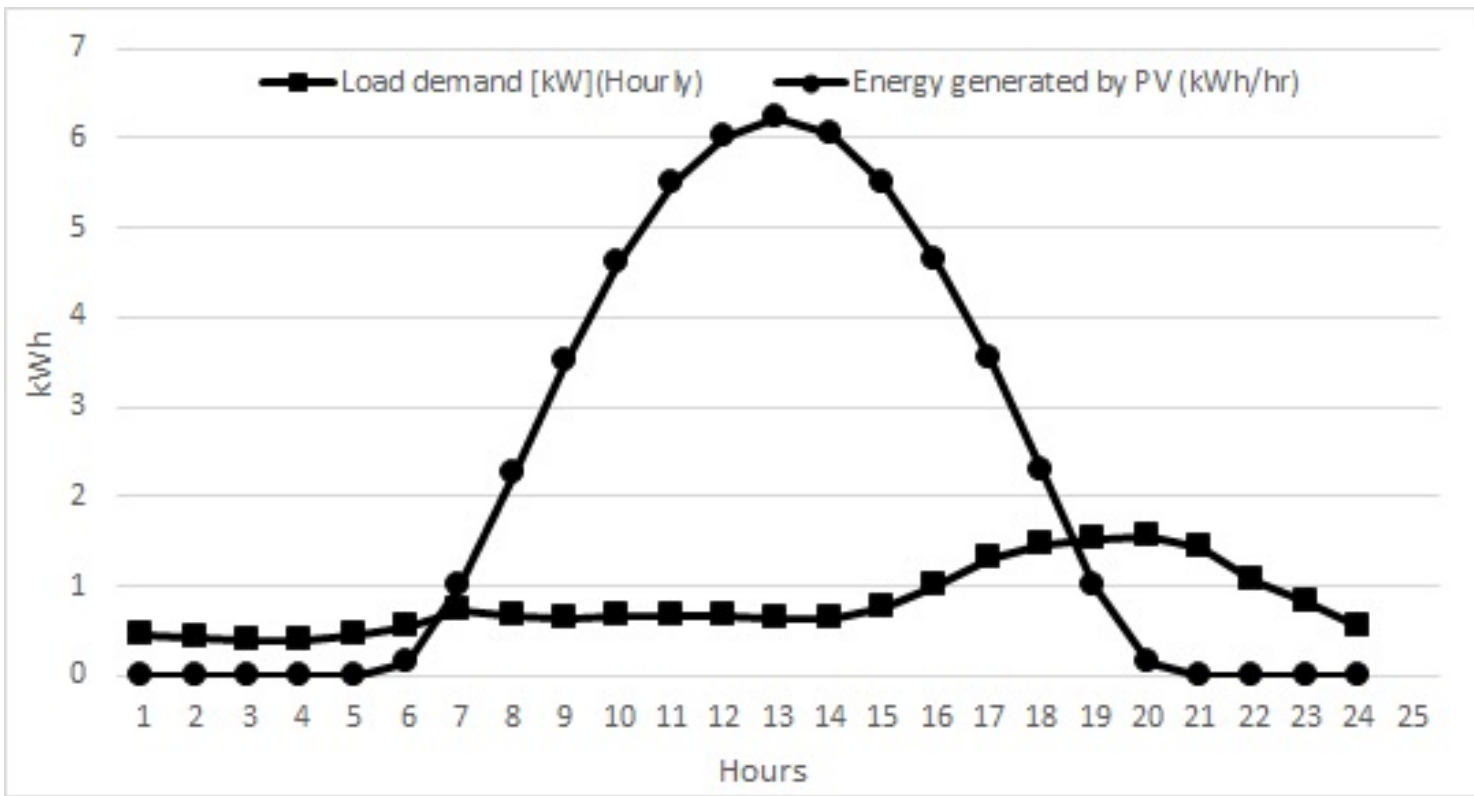

Figure 3. Region Arizona-Prescott: Hourly energy generated by PV and load demand on 1st June. Input: $\eta=17.3 \%, A=33.6 \mathrm{~m}^{2}$ 
Preprint: K.K. Shah, A. S. Mundada, J. M. Pearce. Performance of U.S. Hybrid Distributed Energy Systems: Solar Photovoltaic, Battery and Combined Heat and

Power. Energy Conversion and Management 105, pp. 71-80 (2015). DOI: http://dx.doi.org/10.1016/i.enconman.2015.07.048

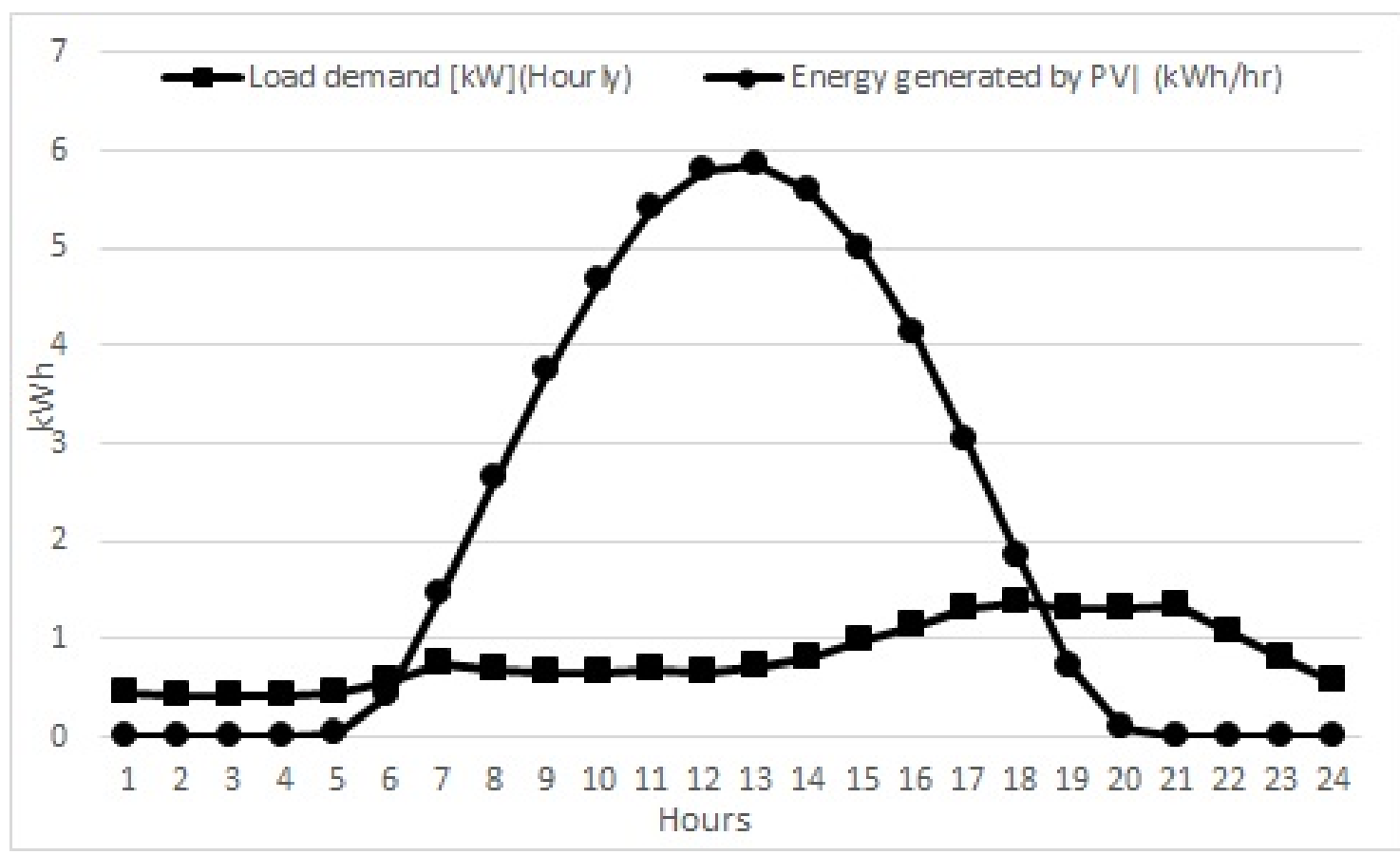

Figure 4. Region California-Sacramento: Hourly energy generated by PV and load demand on 27th June. Input: $\eta=17.3 \%, A=33.6 \mathrm{~m}^{2}$

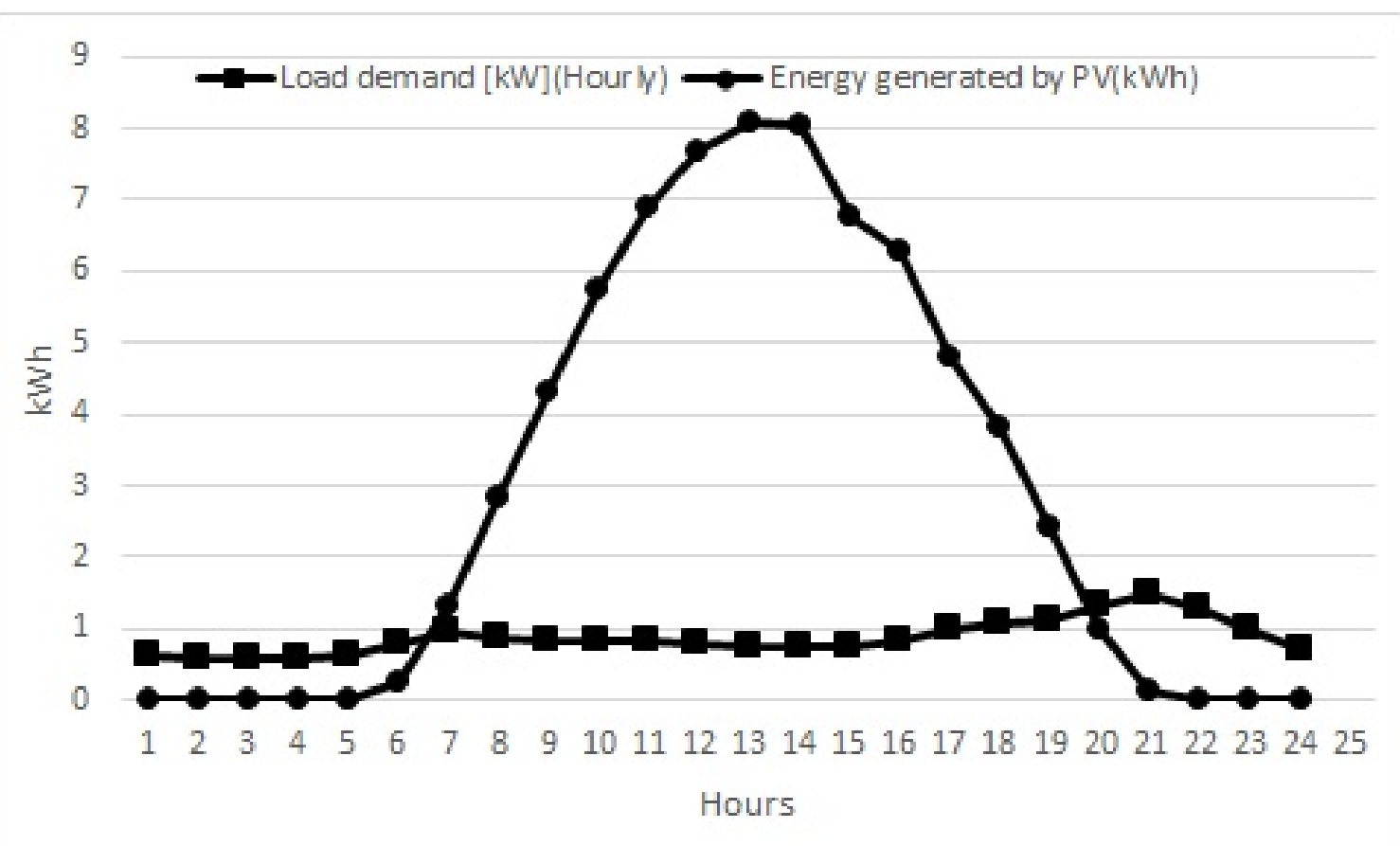

Figure 5. Region Michigan-Houghton: Hourly energy generated by PV and load demand on 1st June. Input: $\eta=17.3 \%, A=49.8 \mathrm{~m}^{2}$

The excess energy generated by the PV $\left(E_{x p v}\right)$ in $\mathrm{kWh}$ is the difference between the hourly energy generated by the PV and the hourly load demand from Figure 4-6 (areas under circles and above squares in the middle of the day in the Figures) which can be calculated using equation 3 and finally adding up the positive differences: 
Where, $\mathrm{E}_{\mathrm{L}}$ is the load demand in $\mathrm{kWh}$. The excessive energy generated by the PV module is 41.17 kWh, $38.47 \mathrm{kWh}, 57.575 \mathrm{kWh}$ for Prescott, Sacramento and Houghton respectively. In order to store this excessive energy size of the battery was determined using equation 4 [46]. The battery used for this purpose is deep cycle lead acid battery with depth of discharge of 50\% and having a nominal voltage of $48 \mathrm{~V}$. B, the battery size in Ah is given by:

$\mathrm{B}=\frac{E_{L} \times A_{d}}{D \times V}$

Where, $A_{d}$ is the days of autonomy, $\mathrm{D}$ is the depth of discharge [\%] and $\mathrm{V}$ is the nominal voltage of the battery [V]. The number batteries that should be connected in parallel $\left(\mathrm{N}_{\mathrm{p}}\right)$ is calculated by [47]:

$N_{p}=\frac{C_{x}}{C_{\text {sel }}}$

Where $C_{x}$ is the battery bank required [Ah] and $C_{\text {sel }}$ is the battery bank selected [Ah]. The number batteries that should be connected in series, $N_{s}$, is [47]:

$N_{s}=\frac{V_{x}}{V_{\text {sel }}}$

Where, $V_{x}$ is the battery voltage required and $V_{\text {sel }}$ is the battery voltage selected, both in [V].

Table 2. Daily Load demand, Excess Power generated

\begin{tabular}{|c|c|c|c|}
\hline Region & $\begin{array}{c}\text { Daily Load Demand } \\
\text { During Peak Summer Day } \\
\text { (kWh) }\end{array}$ & $\begin{array}{c}\text { Excess Power Generated } \\
\text { (kWh) }\end{array}$ & Autonomy Hours \\
\hline Prescott & 19.54 & 41.17 & 25.28 \\
\hline Sacramento & 19.42 & 38.27 & 23 \\
\hline Houghton & 20.96 & 57.57 & 31.95 \\
\hline
\end{tabular}

\subsubsection{CHP sizing}

In order to determine the size of the CHP, the Spark Spread Estimator by EPA CHP (version 1.0) was used. The inputs required are thermal residential load demand [48], annual electrical load demand [38], natural gas price [49], electricity rates [50] and CHP operating hours. Here CHP operating hours are considered during winters, where the CHP will be operating for maximum time (worst case scenario). The input parameters for all the regions are summarized in Table 3. 
Preprint: K.K. Shah, A. S. Mundada, J. M. Pearce. Performance of U.S. Hybrid Distributed Energy Systems: Solar Photovoltaic, Battery and Combined Heat and

Power. Energy Conversion and Management 105, pp. 71-80 (2015). DOI: http://dx.doi.org/10.1016/i.enconman.2015.07.048

Table 3. Thermal demand, Electricity rates, Natural gas price

\begin{tabular}{|c|c|c|c|c|}
\hline Region & $\begin{array}{c}\text { Thermal demand } \\
\text { (MMBTU/year) }\end{array}$ & $\begin{array}{c}\text { Electricity } \\
\text { Rates } \\
\mathbf{( \$ / k W h )}\end{array}$ & $\begin{array}{c}\text { Natural Gas Price } \\
\mathbf{( \$ / M M B T U )}\end{array}$ & $\begin{array}{c}\text { CHP Operating } \\
\text { (hours/year) }\end{array}$ \\
\hline Prescott & 22.45 & 0.1196 & 13.2 & 6570 \\
\hline Sacramento & 35.23 & 0.1239 & 8.8 & 6935 \\
\hline Houghton & 98.4 & 0.1936 & 8.7 & 7665 \\
\hline
\end{tabular}

\section{Results and Discussions}

A summary of the optimized system configurations based for all the three case studies are shown in Table 4. As can be seen in Table 4 all the systems were found to be functional with a $1 \mathrm{kWe}$ CHP unit and reasonably sized PV and battery systems. The economics of such systems is left for future work, however, to explore the results the following sizing data from Table 4 was provided as the input for the simulation the average hourly energy produced per month by all the three units were graphed for all three regions and is shown in. This data is shown in Figures 6-8.

Table 4. Configuration of optimized hybrid PV-Cogen system for all three regions

\begin{tabular}{|c|l|l|l|l|l|}
\hline Region & $\begin{array}{c}\text { Batteries in } \\
\text { parallel }\end{array}$ & $\begin{array}{c}\text { Batteries in } \\
\text { series }\end{array}$ & $\begin{array}{c}\text { PV Size } \\
\mathbf{( k W )}\end{array}$ & $\begin{array}{c}\text { Battery Size } \\
(\mathbf{A h})\end{array}$ & $\begin{array}{c}\text { CHP size } \\
\text { (kWe) }\end{array}$ \\
\hline Prescott & 3 & 8 & 5.4 & 300 & 1 \\
\hline Sacramento & 4 & 1 & 5.8 & 200 & 1 \\
\hline Houghton & 4 & 8 & 8.1 & 300 & 1 \\
\hline
\end{tabular}

From the simulation results hourly power generated by the PV module during the whole year for the region of Prescott, Sacramento and Houghton is shown in Figure 6a, Figure 7a and Figure 8a respectively. The hourly power generated by the CHP module during the whole year for the region of Prescott, Sacramento and Houghton is shown in Figure 6b, Figure $7 \mathrm{~b}$ and Figure 8b, respectively. The state of charge of the battery during the whole year for the region of Prescott, Sacramento and Houghton is shown in Figure 6c, Figure 7c and Figure 8c respectively. By comparing a, b and c in Figure 6-8, the effects of climate on the systems becomes evident. For example, in Houghton where there is a large PV output in the summer, the CHP unit is largely unused and the battery state of charge is high. The opposite is true in the winter, when the CHP unit is on continually and for much larger times than CA or AZ. 
Preprint: K.K. Shah, A. S. Mundada, J. M. Pearce. Performance of U.S. Hybrid Distributed Energy Systems: Solar Photovoltaic, Battery and Combined Heat and

Power. Energy Conversion and Management 105, pp. 71-80 (2015). DOI: http://dx.doi.org/10.1016/i.enconman.2015.07.048

\begin{tabular}{|c|c|c|c|}
\hline Region & $\begin{array}{c}\text { PV power } \\
\text { output(kW) }\end{array}$ & CHP Power output (kW) & Battery State of Charge(\%) \\
\hline Prescott & 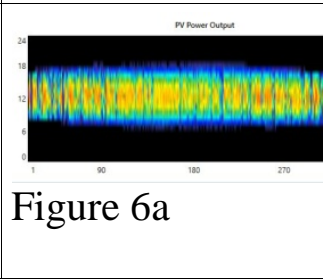 & Figure $6 b$ & 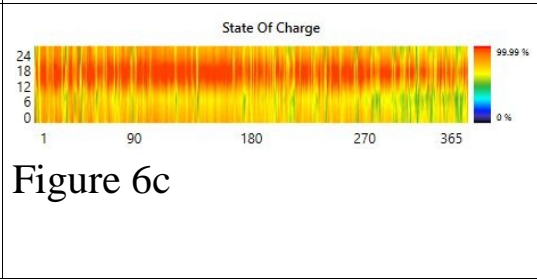 \\
\hline $\begin{array}{c}\text { Sacramen } \\
\text { to }\end{array}$ & 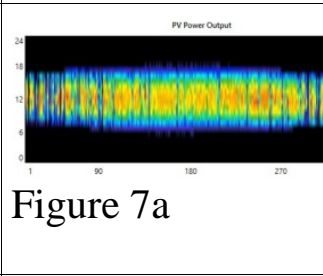 & Figure $7 \mathrm{~b}$ & 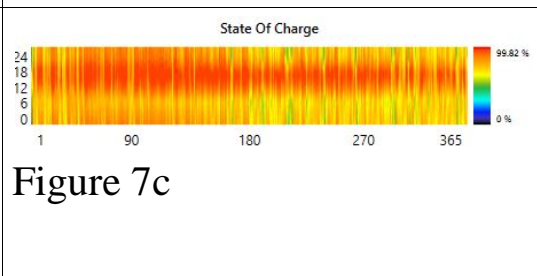 \\
\hline Houghton & 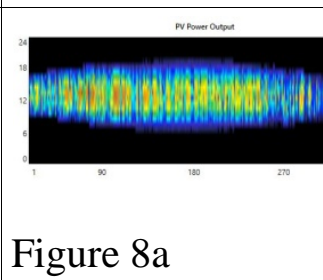 & 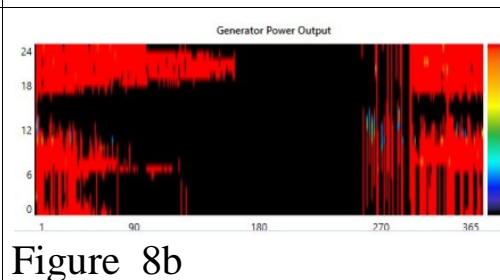 & 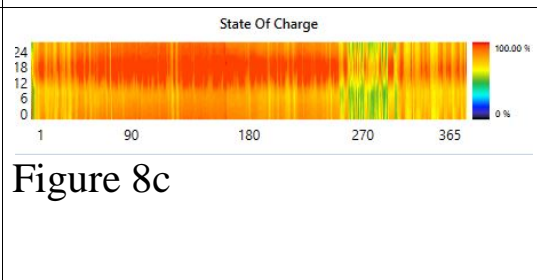 \\
\hline
\end{tabular}


Preprint: K.K. Shah, A. S. Mundada, J. M. Pearce. Performance of U.S. Hybrid Distributed Energy Systems: Solar Photovoltaic, Battery and Combined Heat and

Power. Energy Conversion and Management 105, pp. 71-80 (2015). DOI: http://dx.doi.org/10.1016/i.enconman.2015.07.048

For Prescott, AZ it can observed from Figure 9 that for all the months of the year the load demand has been fulfilled by the contribution of all the three units. In the month of July the load demand is very high due to the use of air-conditioning, as in Prescott the summer temperature goes above $100^{\circ} \mathrm{F}$. In order to fulfill the load demand all the three units are operated, it is observed that the average hourly energy produced by PV, CHP and battery are $0.53 \mathrm{kWh}, 0.38 \mathrm{kWh}, 0.39 \mathrm{kWh}$ respectively for the month of July. On adding up the energy produced by all the three units it can be observed in Figure 9 that it matches with the average hourly load demand which is $1.30 \mathrm{kWh}$ for the month of July. During three month of May the load demand is low which can be fulfilled mostly by the PV and battery units (Figure 5) and the operating hours for the cogeneration unit is less.

For Sacramento, CA it can observed from Figure 10 that for all the months of the year the load demand has been fulfilled by the contribution of all the three units. In January, the solar hours are limited so the energy produced by the PV will be comparatively low. Hence, the remaining load demand is fulfilled by the cogeneration unit. The energy generated by PV, battery and CHP unit during month of January are $0.21 \mathrm{kWh}, 0.30 \mathrm{kWh}, 0.53 \mathrm{kWh}$, respectively. On summing this energy it can be observed from Figure 10 that it matches the hourly load demand which is $1.04 \mathrm{kWh}$ for month of January. The operating hours for the CHP unit is more compared to the operating hours of PV during the month of January as seen in Figure 6. The operating hours for CHP reduces during the summer months compared to winter as the PV and battery can fulfill most of the load demand.

For Houghton, MI it can be observed from Figure 11 that for all months of the year the load demand was fulfilled by the contribution of all the three units. In the month of January the load demand rises up significantly due to space heating, as in Houghton the temperature falls below $8^{\circ} \mathrm{F}$ and all the three units are operated during this month. It can be observed from Figure 11 that energy produced by PV, battery and CHP are $0.27 \mathrm{kWh}, 0.41 \mathrm{kWh}$ and $0.65 \mathrm{kWh}$, respectively during the month of January. As was seen in Figures 7a and 7b, the operating hours of CHP unit is clarger than the PV unit during the month of January. During the months of July and August, the load demand is reduced and the solar hours are increased, thus the battery and PV unit is able to fulfill the load demand. The operating hours for CHP is almost zero during this months as seen in Figure 7, 11.

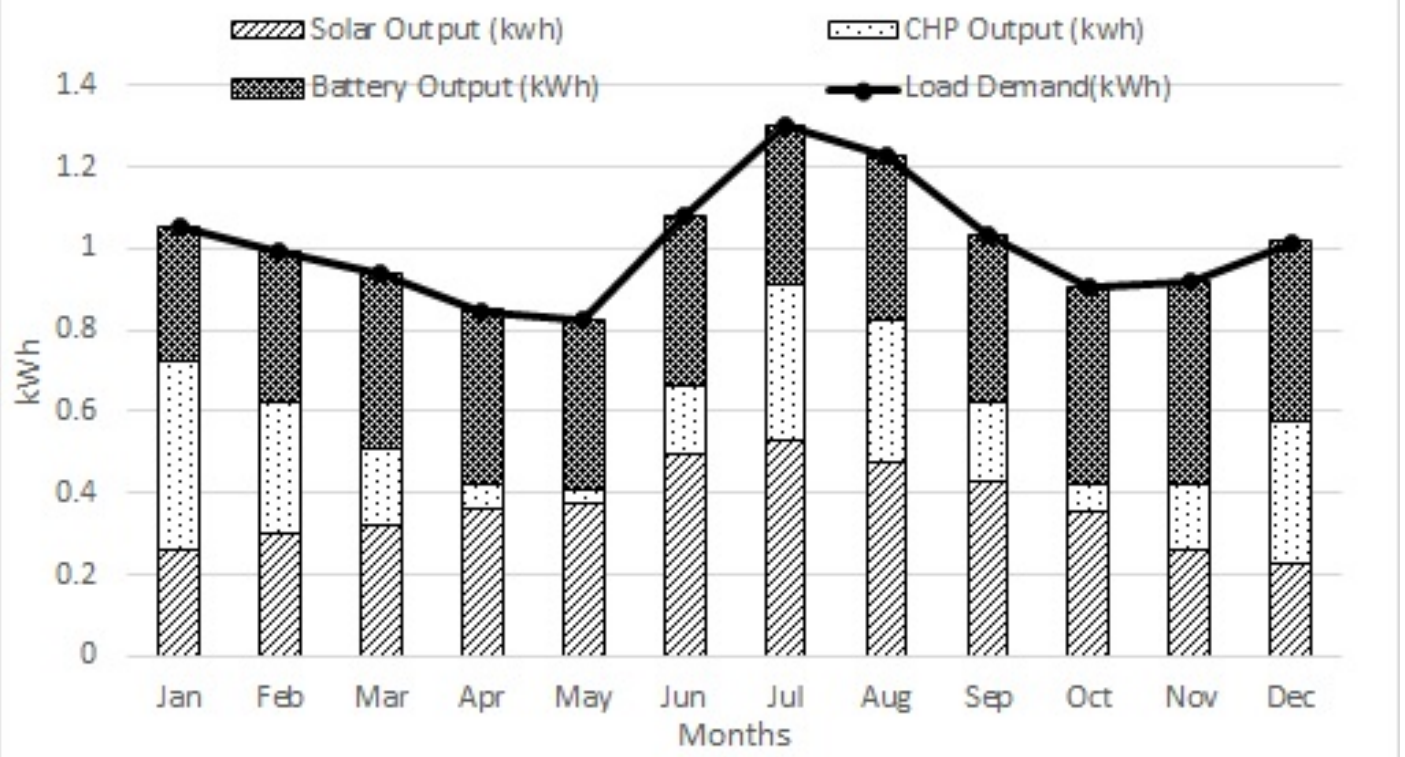

Figure 9. Region: Arizona-Prescott. Average hourly energy produced per month by PV, CHP and battery units to meet the load demand. 
Preprint: K.K. Shah, A. S. Mundada, J. M. Pearce. Performance of U.S. Hybrid Distributed Energy Systems: Solar Photovoltaic, Battery and Combined Heat and

Power. Energy Conversion and Management 105, pp. 71-80 (2015). DOI: http://dx.doi.org/10.1016/j.enconman.2015.07.048

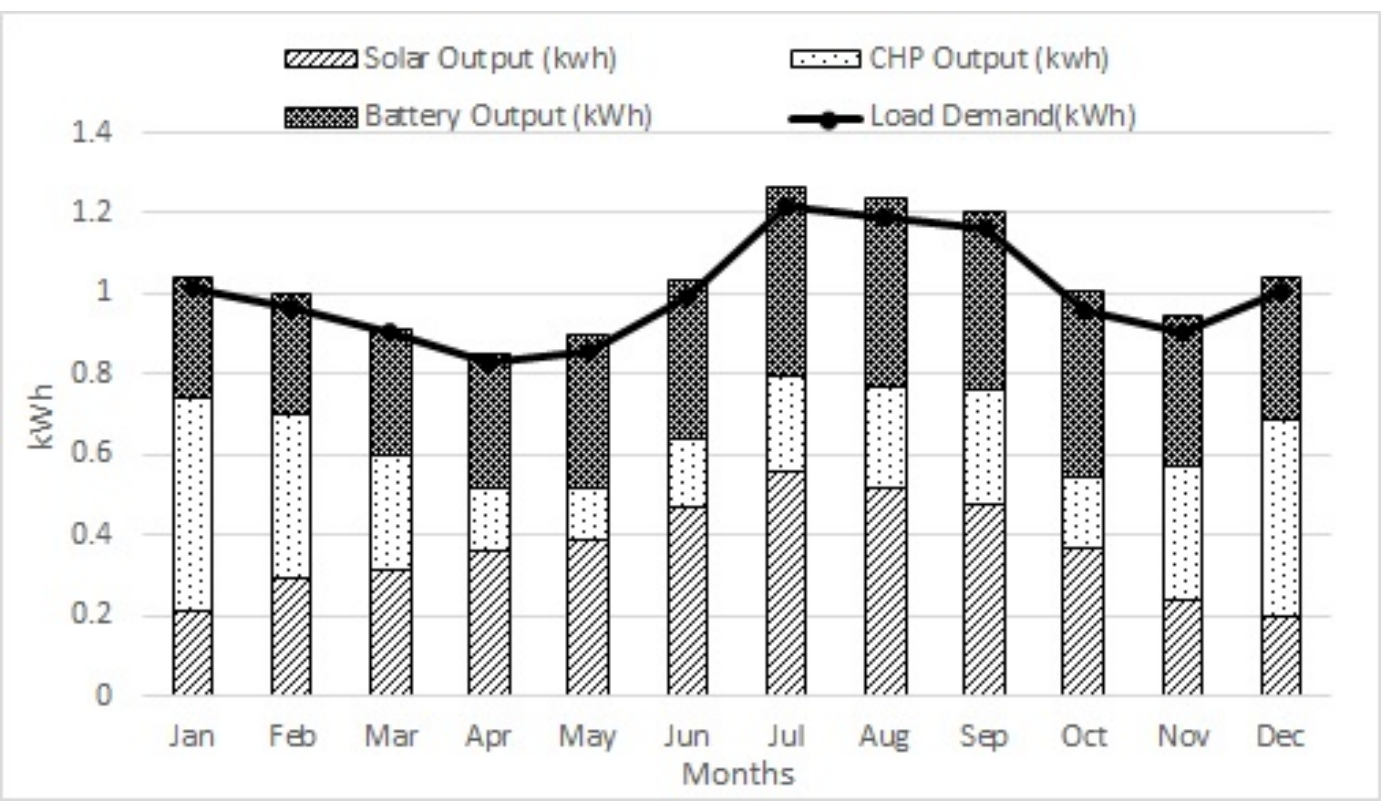

Figure 10 Region: California-Sacramento Average hourly energy produced per month by PV, CHP and battery units to meet the load demand.

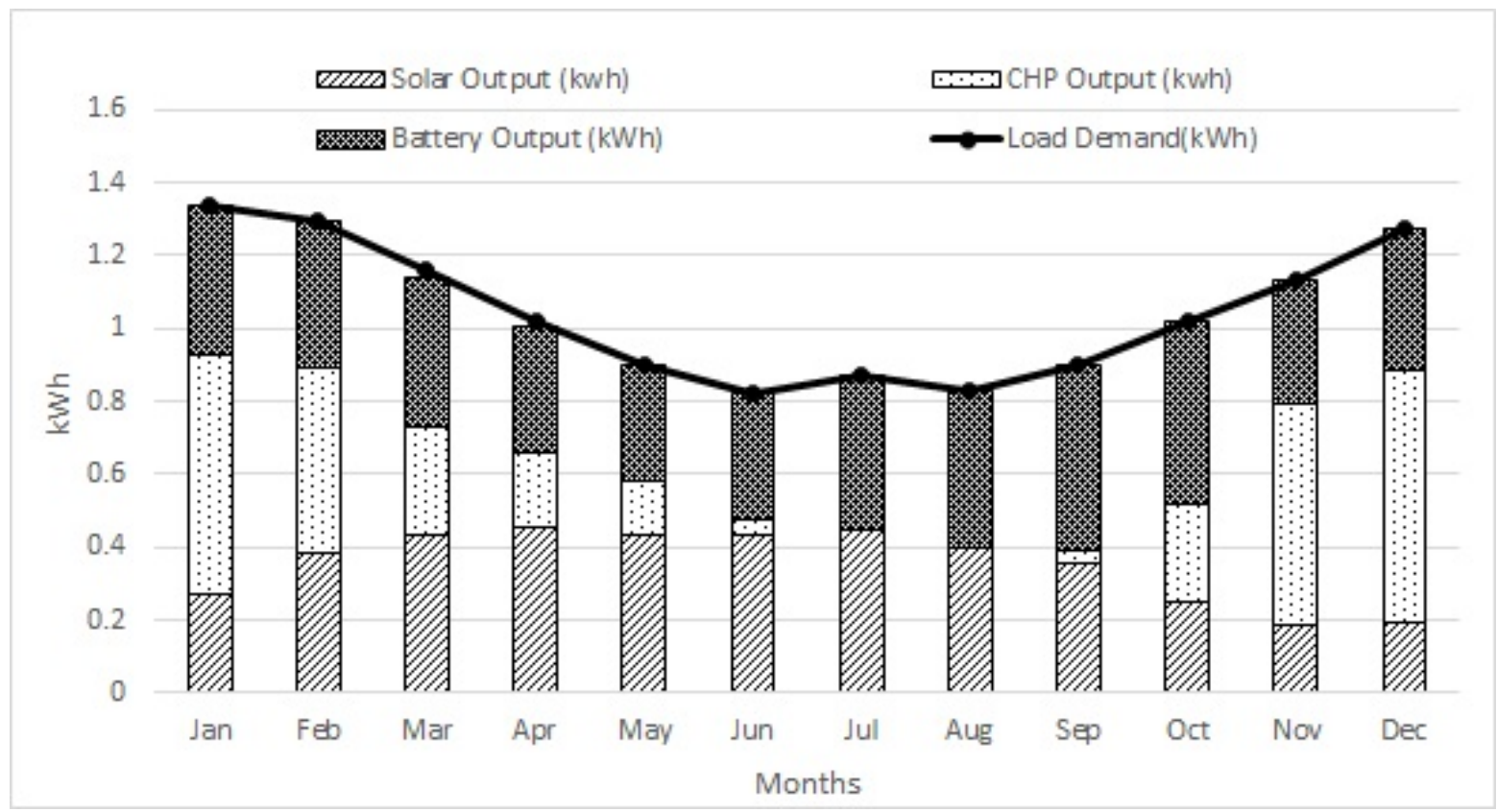

Figure 11. Region: Michigan-Houghton Average hourly energy produced per month by PV, CHP and battery units to meet the load demand.

It is clear from Figure 9-11 that the optimized hybrid system is able to fulfill the load demand for residence in all the 3 regions. It can be observed that the operating hours for all the three units are different for the three regions due to parameters such as solar hours, AC load demand. The PV, battery and the CHP unit were sized appropriately, as they are able to fulfill electrical load demand 
Preprint: K.K. Shah, A. S. Mundada, J. M. Pearce. Performance of U.S. Hybrid Distributed Energy Systems: Solar Photovoltaic, Battery and Combined Heat and

Power. Energy Conversion and Management 105, pp. 71-80 (2015). DOI: http://dx.doi.org/10.1016/i.enconman.2015.07.048

completely for the three regions. However, the annual thermal load demand is fulfilled by the CHP and the boiler unit for the three regions. The individual contribution by each of these units to fulfill the annual thermal demand is obtained from simulation results which is shown in the Table 5.

Table 5. Thermal demand fulfilled by CHP and boiler unit

\begin{tabular}{|c|c|c|c|}
\hline Region & $\begin{array}{c}\text { Required thermal } \\
\text { demand } \\
\text { (MMBTU/year) }\end{array}$ & $\begin{array}{c}\text { Thermal demand satisfied } \\
\text { by CHP unit. } \\
\text { (MMBTU/year) }\end{array}$ & $\begin{array}{c}\text { Thermal demand } \\
\text { satisfied by boiler. } \\
\text { (MMBTU/year) }\end{array}$ \\
\hline Prescott & 22.45 & 15.47 & 6.98 \\
\hline Sacramento & 33.23 & 19.89 & 13.34 \\
\hline Houghton & 98.4 & 18 & 80.4 \\
\hline
\end{tabular}

The thermal demand that is fulfilled by CHP unit is around $70 \%, 56 \%$ and $20 \%$ for Prescott, Sacramento and Houghton, respectively and the remaining thermal demand is fulfilled by the boiler unit.

\section{Sensitivity Analysis}

From the results shown above for all the three regions sensitivity analysis has been carried out on the energy generated by PV and CHP units by varying the capacity factor of each, while ensuring the total energy generated by PV and CHP unit together remains constant in order to fulfill the load demand. The rated energy for the PV and CHP system depends on the capacity factors of the systems. The energy generated by the CHP can be calculated by multiplying number of days in a year with the capacity factor of the CHP, which is then multiplied by the number of hours in a day and CHP size in $\mathrm{kW}$ equation 7. For the PV system the rated energy can be calculated by multiplying the number of days in a year with the capacity factor of the PV, which is then multiplied by the number of hours in a day and system size in $\mathrm{kW}$ equation 8 . The change in the capacity factor of PV module changes the rated output of the PV module. This will change the rated output of the CHP. The total output of the system is maintained constant as it is able to satisfy the electrical load demand. The capacity factor for PV and the CHP unit is obtained from the simulation results for all the three regions and is shown in Table 6.

$E_{P V}=365 \times 24 \times S_{P V} \times C_{P V}$

Where, $S_{P V}$ is the size of PV [kW] and $C_{P V}$ is the capacity factor of PV [\%].

$E_{C H P}=365 \times 24 \times S_{C H P} \times C_{C H P}$

Where $E_{\text {CHP }}$ is the yearly energy generated by CHP [kWh], ${ }^{S_{C H P}}$ is the size of CHP [kW] and $C_{C H P}$ is the capacity factor of CHP [\%]. 
Table 6. Capacity Factor and Energy generated by PV and CHP

\begin{tabular}{|c|c|c|c|c|c|}
\hline Region & $C_{P V}(\%)$ & $C_{C H P}(\%)$ & $\begin{array}{c}E_{P V} \\
(\mathrm{kWh} / \text { year })\end{array}$ & $\begin{array}{c}E_{C H P} \\
(\mathrm{kWh} / \mathrm{year})\end{array}$ & $\begin{array}{c}E_{C H P+P V} \\
(\mathrm{kWh} / \text { year })\end{array}$ \\
\hline Prescott & 19.3 & 26.3 & 9,294 & 2,302 & 11,595 \\
\hline Sacramento & 19.7 & 33.9 & 10,003 & 2,973 & 12,975 \\
\hline Houghton & 15.4 & 30.0 & 10,957 & 2,634 & 13,591 \\
\hline
\end{tabular}

The energy generated by the CHP unit is affected by changing the capacity factor of the PV. The effect of capacity factor of PV on the capacity factor of CHP is shown in Table 7. Energy produced by PV and CHP unit is calculated by equation 6 and equation 7 respectively, whereas the total energy produced by PV and CHP unit together is kept constant in order to meet the load demand. The energy generated by PV and CHP unit for various capacity factors from Table 7 for the three different regions is shown in Figure 12-14. As the capacity factor of PV increases, the capacity factor of CHP unit decreases and hence the energy generated by the CHP unit decreases. From Figure 12 when the capacity factor of PV is $22 \%$ and capacity factor of CHP is $11 \%$ the energy generated by the CHP unit is minimum i.e. $997 \mathrm{kWh}$.

Table 8. Different Capacity Factors of PV and CHP unit

\begin{tabular}{|l|l|l|}
\hline Region & \multicolumn{1}{|c|}{$C_{P V}(\%)$} & $C_{C H P}(\%)$ \\
\hline Prescott & 17 & 38.87 \\
\hline & 19.28 & 26.28 \\
\hline & 22 & 11.37 \\
\hline Sacramento & 15 & 61.12 \\
\hline & 19.68 & 33.94 \\
\hline & 25 & 3.12 \\
\hline Houghton & 12 & 57.55 \\
\hline & 15.38 & 30.08 \\
\hline & 18 & 8.76 \\
\hline
\end{tabular}


Preprint: K.K. Shah, A. S. Mundada, J. M. Pearce. Performance of U.S. Hybrid Distributed Energy Systems: Solar Photovoltaic, Battery and Combined Heat and

Power. Energy Conversion and Management 105, pp. 71-80 (2015). DOI: http://dx.doi.org/10.1016/i.enconman.2015.07.048

\section{Limitations and Future work}

It is clear from the results of this analysis that for all of the U.S. regions investigated it is possible to make a reasonably sized PV+battery+CHP system to meet the average load demand on an hourly basis of a typical residential home. Further work is needed to investigate load demands on a more granular basis. Large short power draws for example would not be possible with such a system always being limited to the power available from the combination of all three subsystems in the best of times and perhaps only one system (e.g. CHP) unit in overcast days or night. Such low-emission off-grid systems would entail potential behavior modifications of users and future work is needed into the social acceptability of this transition assuming economic viability and environmental benefits. It should be noted here that this case of a single family residence represents the most extreme case of load demands. Although there are clear benefits to distributed power systems over the central grid [51], by coupling even a modest number of residences together in a microgrid [52] in various locations throughout the world [53] offers significant advantages that need further investigation [54].

To quantify the environmental benefits, in the future GHG emissions could be taken into consideration for designing the hybrid systems as the CHP unit is not free of greenhouse gas emissions. CHP offers reductions in total primary fuel consumption on the order of $30 \%$ to $35 \%$ [55]. However, natural-gas fired CHP systems results in $\mathrm{CO}_{2}$ emission reductions approaching $60 \%$ and even greater reductions in pollutants such as $\mathrm{SO}_{2}, \mathrm{NO}_{\mathrm{x}}$ and mercury [55]. The GHG emissions should be considered in a dynamic [56] and further work can investigate distributed CHP using bioderived fuels. Future work is also necessary to determine the greenhouse gas liability [57-58] and other economic costs dynamically into the future, which can be factored into the economics discussed below. In addition, it is important future work to quantify the environmental impact of such PV+CHP+battery hybrid systems and compare it to the grid's impact in different locations, as well as to PV+battery systems and CHP+battery systems using life cycle analysis. Moreover, in order to increase the system efficiency, an absorption chiller can be installed to the CHP unit (CCHP) to utilize maximum heat energy available and such systems should be simulated over the same geographic locations. This is particularly important when a CHP unit with absorption chiller is used as a backup to PV module during hot days as the waste heat from the CHP can be utilized for cooling purpose [23]. In addition, future work can investigate the potential of pulling heat from the back of the PV modules, to increase their efficiency and help address thermal loads.

Finally, it should be noted that results of modeling based as the single family residence can be misinterpreted to provide an erroneously high estimate for the value of the centralized grid [59]. This study has shown that centralized grid is no longer necessary to provide reliable electric power with only modest sized systems even for a single family residence. Thus, rather than use large sunk costs of conventional power systems to estimate "value of the grid", hybrid distributed systems like those described in this paper should be those to determine such value. Utilizing the simulation results obtained in this paper, a new methodology of calculating the levelized cost of electricity (LCOE) of hybrid system can be carried out and is underway [60]. This methodology should also be expanded to distributed hybrid microgrids as they are likely to result in lower costs already observed for CHP systems alone.

\section{Conclusions}

This study has demonstrated the off-grid residential-scale hybrid energy systems incorporating solar 
Preprint: K.K. Shah, A. S. Mundada, J. M. Pearce. Performance of U.S. Hybrid Distributed Energy Systems: Solar Photovoltaic, Battery and Combined Heat and

Power. Energy Conversion and Management 105, pp. 71-80 (2015). DOI: http://dx.doi.org/10.1016/i.enconman.2015.07.048

photovoltaic, batteries and a cogeneration unit are able to meet electrical load demands throughout the U.S. using reasonable sized components. The results of this study indicate that such $\mathrm{PV}+\mathrm{CHP}+$ battery hybrid systems can provide all of the necessary electricity in Prescott, Arizona (representing a hot climate), Sacramento, California (representing a moderate climate) and Houghton, Michigan (representing a cold climate). Thus, such PV+CHP+battery hybrid systems provide the potential for America to transition away from a centralized grid, while reducing emissions and potentially costs while overcoming the inherent challenges of intermittency of PV.

\section{Acknowledgements}

The authors would like to thank T. Stanton for helpful discussions.

\section{References}

1. Intergovernmental Panel on Climate Change, Climate Change. Synthesis report. Cambridge University Press, Cambridge, UK; 2007.

2. Intergovernmental Panel on Climate Change, Climate Change. Mitigation of climate change. Cambridge University Press, Cambridge, UK; 2007.

3. Moss RH, Edmonds JA, Hibbard KA, Manning MR, Rose SK, Van Vuuren DP, Carter TR, Emori S, Kainuma M, Kram T, Meehl GA, Mitchell JF, Nakicenovic N, Riahi K, Smith SJ, Stouffer RJ, Thomson AM, Weyant JP, Wilbanks TJ. The next generation of scenarios for climate change research and assessment. Nature 2010;463(7282):747-756.

4. Stern N H, Stern Review: The economics of climate change. Vol. 30. London: HM Treasury; 2006.

[5] Sirchis J. Combined Production of Heat and Power. New York: Elsevier; 2005.

[6] International Energy Agency. Electricity information 2008. Paris, France: International Energy Agency; 2008.

[7] Tozer R, Serrano ML, Capilla AV, James R. Thermoeconomics applied to an air conditioning system with cogeneration. Building Services Engineering Research and Technology 1996; 17(1):3742.

[8] Liu M, Shi Y, Fang F. Combined cooling, heating and power systems: A survey. Renewable and Sustainable Energy Reviews 2014; 35:1-22.

[9] Huangfu Y, Wu J, Wang R, Kong X, Wei B. Evaluation and analysis of novel micro-scale combined cooling, heating and power (MCCHP) system. Energy Convers Manag 2007;48(5):17039.

[10] Bilgen E. Exergetic and engineering analyses of gas turbine based cogeneration systems. Energy 2000;25(12):1215-29.

[11] Havelsky V. Energetic efficiency of cogeneration systems for combined heat, cold and power production. Int. J Refrig1999;22(6):479-85.

[12]EESI, 2013. Combined Heat and Power: Pathway to Lower Energy Costs, Reduced Emissions, Secure and Resilient Energy Supply. (visited 5.13.2015)Available at: http://www.eesi.org/files/FactSheet_CHP_052113.pdf

[13] U.S. Department of Energy (DOE) and U.S. Environmental Protection Agency (EPA). Combined Heat and Power: A Clean Energy Solution. DOE/EE-0779. August 2012. (visited 5.13.2015)Available at - http://www.epa.gov/chp/documents/clean_energy_solution.pdf.

[14] Dorer V, Weber A. Energy and CO2 emissions performance assessment of residential microcogeneration systems with dynamic whole-building simulation programs. Energy Conversion and Management 2009; 50(3):648-657. 
Preprint: K.K. Shah, A. S. Mundada, J. M. Pearce. Performance of U.S. Hybrid Distributed Energy Systems: Solar Photovoltaic, Battery and Combined Heat and Power. Energy Conversion and Management 105, pp. 71-80 (2015). DOI: http://dx.doi.org/10.1016/i.enconman.2015.07.048

[15] Feng X, Cai YN, Qian LL. A new performance criterion for cogeneration system. Energy Conversion and Management 1998; 39(15):1607-1609.

[16] Gamou S, Yokoyama R, Ito K. Optimal unit sizing of cogeneration systems in consideration of uncertain energy demands as continuous random variables. Energy Conversion and Management 2002;43(9):1349-1361.

[17] Çakir U, Çomakli K, Yüksel F. The role of cogeneration systems in sustainability of energy. Energy Conversion and Management 2012;63:196-202.

18. Pearce JM. Expanding photovoltaic penetration with residential distributed generation from hybrid solar photovoltaic and combined heat and power systems. Energy 2009; 34(11):1947-1954. 19. Mostofi M, Nosrat AH, Pearce, JM. Institutional scale operational symbiosis of photovoltaic and cogeneration energy systems. Int. J. Environ. Sci. Tech. 2011; 8(1):31-44.

20. Nosrat AH, Pearce, JM. Dispatch Strategy and Model for Hybrid Photovoltaic and Combined Heating, Cooling, and Power Systems. Applied Energy 2011; 88:3270-3276.

21. Carmeli MS, Castelli-Dezza F, Mauri M, Marchegiani G, Rosati D. Control strategies and configurations of hybrid distributed generation systems. Renewable Energy 2012;41:294-305. 22. Ismail, M S, Moghavvemi M, Mahlia TMI. Design of an optimized photovoltaic and microturbine hybrid power system for a remote small community: case study of Palestine. Energy Conversion and Management 2013;75:271-281.

23. Nosrat AH, Swan LG,Pearce, JM. Improved Performance of Hybrid Photovoltaic-Trigeneration Systems Over Photovoltaic-Cogen Systems Including Effects of Battery Storage. Energy 2013; 49:366-374.

24. Basrawi F, Yamada T, Obara SY. Economic and environmental based operation strategies of a hybrid photovoltaic-microgas turbine trigeneration system. Applied Energy 2014; 121:174-183. 25. Hosseini M, Dincer I, Rosen MA. Thermodynamic and Cost Analyses of a Residential Hybrid PV-Fuel Cell-Battery System for a Canadian House. In Progress in Exergy, Energy, and the Environment (pp. 181-191). Springer International Publishing, 2014.

26. Brandoni C, Renzi M. Optimal sizing of hybrid solar micro-CHP systems for the household sector. Applied Thermal Engineering 2015;75:896-907.

27. Helal A, Ghoneim W, Halaby A. Feasibility Study for Self-Sustained Wastewater Treatment Plants-Using Biogas CHP Fuel Cell, Micro-Turbine, PV and Wind Turbine Systems. Smart Grid and Renewable Energy 2013;4:227-235.

28. Maghanki MM, Ghobadian B, Najafi G, Galogah RJ. Micro combined heat and power (MCHP) technologies and applications. Renewable and Sustainable Energy Reviews 2013; 28:510-524.

29. Bando S, Asano H, Tokumoto T, Tsukada T, Ogata T. Optimal operation planning of a photovoltaic-cogeneration-battery hybrid system. In Power System Technology, 2006. PowerCon 2006. International Conference on (pp. 1-8). IEEE.

30. Ashari M, Nayar C V. An Optimum Dispatch Strategy Using Set Points for Photovoltaic (PV)Diesel Battery Hybrid Power System. Solar Energy 1999; 66(1):1-9.

31. Borowy B, Salameh Z. Methodology for optimally sizing the combination of a battery bank and PV Array in a Wind/PV Hybrid system. IEEE Trans Energy Convers 1995;11(2):367-75.

32. Branker K, Pathak MJM, Pearce JM. A review of solar photovoltaic levelized cost of electricity. Renewable and Sustainable Energy Reviews 2011;15(9):4470-4482.

33. U.S. Department of Energy, Grid Energy Storage, December 2013. U.S. Department of Energy Available:

http://energy.gov/sites/prod/files/2014/09/f18/Grid\%20Energy\%20Storage\%20December\%202013. $\underline{\mathrm{pdf}}$

34. Rocky Mountain Institute. Economics of Grid Defection: When and Where Distributed Solar Generation Plus Storage Competes with Traditional Utility Service. Colorado:Rocky Mountain 
Preprint: K.K. Shah, A. S. Mundada, J. M. Pearce. Performance of U.S. Hybrid Distributed Energy Systems: Solar Photovoltaic, Battery and Combined Heat and

Power. Energy Conversion and Management 105, pp. 71-80 (2015). DOI: http://dx.doi.org/10.1016/i.enconman.2015.07.048

Institute, 2014.

35. Rogers A, Hayman G, Avelar CT, McGowan JG, Abdulwahid U, Wu K. Hybrid2: A Hybrid System Simulation Model: Theory Manual. National Renewable Energy Laboratory, 1998.

36. Green HJ, Manwell J. HYBRID2: A Versatile Model for the Performance of Hybrid Systems.

Report by National Renewable Energy Laboratory, 1992.

37. Carmeli MS, Castelli-Dezza F, Marchegiani G, Mauri M, Piegari L, Rosati D. Hybrid PV-CHP distributed system: Design aspects and realization. In Clean Electrical Power, 2009 International Conference on (pp. 782-789). IEEE, 2009.

38. DOE-Open EI, Datasets. Commercial and Residential hourly load profile. Available at:

$<$ http://en.openei.org/doe-opendata/dataset/commercial-and-residential-hourly-load-profiles-for-alltmy3-locations-in-the-united-states/resource/b341f6c6-ab5a-4976-bd07-adc68a2239c4>

39. System Advisor Model (SAM-2015 1.30) Available at: https://sam.nrel.gov/content/downloads 40. Maharaja K, Sangeetha S, Mareeswari K. Sizing of Solar PV Power Plant in Stand-Alone Operation”. International Journal of Engineering Research \& Technology 2014; 3(6):

http://www.ijert.org/view-pdf/9972/sizing-of-solar-pv-power-plant-in-stand-alone-operation 41. Photovoltaic Design Assistance Center Sandia National Laboratories.Standalone Photovoltaic Systems A handbook of recommended design Practices. Albuquerque, New Mexico: Photovoltaic Design Assistance Center Sandia National Laboratories, 1995.

42. National Renewable Energy Laboratory. National Solar Radiation Data Base. Available at: http://rredc.nrel.gov/solar/old_data/nsrdb/

43. National Renewable Energy Laboratory. Calculator for Overall DC to AC Derate Factor. Available at: http://rredc.nrel.gov/solar/calculators/pvwatts/version1/derate.cgi.

45. Ru Y, Kleissl J, Martinez S. Storage size determination for grid-connected photovoltaic systems. IEEE Transactions on Sustainable Energy 2013;4(1):68-81.

46. Herteleer, B., Cappelle, J., \& Driesen, J. An autonomous photovoltaic system sizing program for office applications in Africa. International Conference on Renewable Energies and Power Quality; 2012. Available at: https://lirias.kuleuven.be/bitstream/123456789/342896/1/450-herteleer.pdf 47. Feng W, Slameh ZM. Off-Grid Photovoltaic System Design for Haiti School Project. Journal of Power and Energy Engineering 2014;2(11): 24-32.

48. Energy Information Administration. Household Energy Use. Energy Information Administration. 2009. Available at : www.eia.gov/consumption/residential/.

49. Energy Information Administration. Natural gas rates. U.S. Energy Information Administration; 2015. Available at: http://www.eia.gov/dnav/ng/ng_pri_sum_dcu_SMI_a.htm. 50. Electricity Local. Electricity local Rates and Usage. 2015. Available at: http://www.electricitylocal.com/.

51. Davis MW. Distributed resource electric power systems offer significant advantages over central station generation and T \& D power systems. II. In Power Engineering Society Summer Meeting, 2002 IEEE (Vol. 1, pp. 62-69). IEEE.

52. Zhang D, Evangelisti S, Lettieri P, Papageorgiou LG. Optimal design of CHP-based microgrids: Multiobjective optimisation and life cycle assessment. Energy. 2015 (in press).

53. Siddiqui J M. Grid parity analysis of stand-alone hybrid microgrids: A comparative study of Germany, Pakistan, South Africa and the United States. Thesis. Rochester Institute of Technology.

2015. Available at: http://scholarworks.rit.edu/theses/8606

54. Martinot E, Kristov L, Erickson JD. Distribution System Planning and Innovation for Distributed Energy Futures. Current Sustainable/Renewable Energy Reports 2015; 1-8.

55. Quinn J, James F, Whitaker C. Pace Global,"Combined Heat \& Power, 2013: Are We There Yet? ACEEE, 2013. Available at: http://aceee.org/files/proceedings/2013/data/papers/4_162.pdf 56. Kenny R, Law C, Pearce JM. Towards real energy economics: energy policy driven by life- 
cycle carbon emission. Energy Policy 2010;38(4):1969-1978.

57. Allen M. Liability for climate change. Nature 2003. 421(6926); 891-892.

58. Heidari N, Pearce JM. A Review of Greenhouse Gas Emission Liabilities as the Value of Renewable Energy for Mitigating Lawsuits for Climate Change Related Damages (to be published). 59. EPRI. The Integrated Grid: Realizing the Full Value of Central and Distributed Energy Resources. EPRI, 2014. Available at:

http://www.epri.com/abstracts/Pages/ProductAbstract.aspx?ProductId=000000003002002733 60. Aishwarya S. Mundada, Kunal K. Shah, J.M. Pearce. Levelized Cost of Electricity for Solar Photovoltaic and Cogen Hybrid Systems (to be published). 